\title{
Pharmacogenomics of sickle cell disease: steps toward personalized medicine
}

\author{
Marium Husain' \\ Amber D Hartman² \\ Payal Desai ${ }^{3}$ \\ 'Division of Medical Oncology, \\ ${ }^{2}$ Division of Palliative Medicine, \\ ${ }^{3}$ Division of Hematology, The Ohio \\ State University Wexner Medical \\ Center, Columbus, $\mathrm{OH}, \mathrm{USA}$
}

This article was published in the following Dove Press journal:

Pharmacogenomics and Personalized Medicine

19 October 2017

Number of times this article has been viewed

\begin{abstract}
Sickle cell disease (SCD) is a monogenetic disease but has a wide range of phenotypic expressions. Some of these differences in phenotype can be explained by genetic polymorphisms in the human globin gene. These polymorphisms can result in different responses to typical treatment, sometimes leading to inadequate therapeutics. Research is revealing more polymorphisms, and therefore, new targets for intervention to improve outcomes in SCD. This area of pharmacogenomics is continuing to develop. We provide a brief review of the current literature on pharmacogenomics in SCD and possible targets for intervention.
\end{abstract}

Keywords: sickle cell disease, pharmacogenomics, hydroxyurea, opioids, HbF inducers, gene therapy

\section{Introduction}

Sickle cell disease (SCD) was the first described genetic disorder. It results from the substitution of a valine for a glutamine affecting the hemoglobin structure as a result of substitution of $\mathrm{A}$ to $\mathrm{T}$ on chromosome 11 in the $\beta$-globin gene. The resultant hemoglobin is more rigid and less soluble compared to its normal counterpart. The homozygous form results in vaso-occlusion in vascular beds, resulting in pain and chronic organ dysfunction.

Although SCD is a monogenetic disease, there is vast variation in the phenotypic expression. Data demonstrates that there are variable haplotypes in SCD that effect $\mathrm{HbF}$ expression. Additional genetic variations may affect the efficacy of both hydroxyurea (HU), a disease-modifying therapy, and opioid therapy.

\section{HU}

$\mathrm{HU}$, also known as hydroxycarbamide, is a ribonucleotide reductase inhibitor that works via multiple mechanisms. It can help with $\mathrm{HbF}$ induction, decreases adhesion molecules, and decreases white blood cells. ${ }^{1} \mathrm{HU}$ increases $\mathrm{HbF}$ production through its effect on human $\beta$-globin genes $(H B B)$. Although this medication is the only US Food and Drug Administration-approved treatment for SCD, there are nonresponders and patients with intolerance to $\mathrm{HU}^{2}$ There have been a reported $25 \%$ of SCD and $\beta$-thalassemia patients that are poor responders or nonresponders to $\mathrm{HU}$ and have variation in the production of $\mathrm{HbF}^{3}$ It is likely that genetic makeup plays a role, as evidenced by showing the hereditary component in HbF induction with HU treatment. ${ }^{4}$ Tafrali, et $\mathrm{al}^{5}$ studied the $M A P 3 K 5$ gene and found two single-nucleotide polymorphisms (SNPs) in the intron 1 region that were confirmed to have a correlation with
Correspondence: Payal Desai Division of Hematology, The Ohio State University Wexner Medical Center, 320 West I0th Ave, A354 Starling Loving Hall, Columbus, $\mathrm{OH} 43235$, USA

Tel +l 6142932887

Fax +I 6142937526

Email Payal.Desai@osumc.edu 
increased HU response in heterozygous $\mathrm{SCD} / \beta$-thalassemia patients. However, they also suggest that there may be an unknown associated genetic polymorphism that influences the $M A P 3 K 5$ gene as this gene has not been found to be clearly associated with erythropoiesis. Chalikiopoulou ${ }^{6}$ also found an association between the ASS1, NOS1, and NOS2A gene polymorphisms and HU treatment efficacy. These genes are involved in enzyme processing for nitric oxide (NO) synthesis. NO is known to be associated with $\mathrm{HbF}$ induction.

The genetic modifier KLF10 may lead to haploinsufficiency and has been found in SCD patients. ${ }^{7}$ One study analyzed the KLF10 gene and found that it was one of the major genes expressed in vitro in human erythroid progenitor cells when treated with HU. ${ }^{8}$ They proposed that KLF10 can be used as a pharmacogenomic marker for efficacy of $\mathrm{HU}$ treatment in $\beta$-hemoglobinopathy patients, including those with SCD. Their study was specifically in $\beta$-thalassemia/ SCD compound heterozygous patients. Other markers were studied by Steinberg et al, ${ }^{9}$ who found that the absence of a $\beta$-globin haplotype, the CAR, was associated with a higher $\mathrm{HbF}$ response with $\mathrm{HU}$ treatment. Alternatively, poor response and death from acute chest syndrome was seen in SCD patients who were homozygous in the BAN haplotype and heterozygous in the CAM haplotype. ${ }^{10}$ Kumkhaek et al, ${ }^{11}$ found five SNPs in the $S A R 1 A$ gene that was also correlated with $\mathrm{HbF}$ expression after 2 years of $\mathrm{HU}$ treatment.

Gene markers found to have a response to $\mathrm{HU}$ in children include $A R G 1, A R G 2, B C L 11 A$, and two SNPs in the $H B B$ locus. ${ }^{12}$ Interestingly, $B C L 11 A$ is not present on the $\beta$-globin gene cluster but still has an effect on $\mathrm{HbF}$ production. ${ }^{13}$

The Xmn 1 polymorphism has been associated with higher levels of $\mathrm{HbF}$ upon treatment with HU. However, this has been shown in patients with $\beta$-thalassemia. ${ }^{14,15}$ Finding genetic variations that lead to a nonresponder phenotype is important as HU does have side effects. Some common side effects include cytopenias, hyperpigmentation, weight gain, and possible teratogenic effects. ${ }^{16}$ If the patient is known to be a nonresponder, exposure to potential side effects may be avoided.

A full list of genes involved in response to $\mathrm{HU}$ is listed in Table 1.

\section{Opioids}

Opioids are currently the primary treatment modality for pain in sickle cell crisis. Many sickle cell patients also require chronic opioid therapy to optimize functional status so that they are not debilitated by their chronic pain. However, there is variability in response to opioids among SCD patients.
Many times, a lack of response at typical opioid doses is perceived as an aberrant behavior by the medical team. However, known polymorphisms in the COMT, OPRM1, and $A B C B 1$ genes can lead to an altered perception of pain and/or a change in response to opioids. ${ }^{17,18}$ Additionally, the pharmacokinetics of opioids can be altered by genetically mediated variability in the activity of CYP enzymes and by organ dysfunction of SCD. This combination of factors results in a complicated clinical presentation.

COMT is the enzyme that breaks down dopamine, norepinephrine, and adrenaline. All of these neurotransmitters play a part in the modulation of pain. Genetic polymorphisms can lead to a 3-4-fold difference in the activity of this enzyme, likely altering pain sensitivity. ${ }^{19}$ OPRM1 codes for the human mu-opioid receptor. Polymorphisms in OPRM1 can lead to varied morphine metabolism and mu receptor expression. Although little research has been done regarding the predictive value of COMT or OPRM1 polymorphisms in SCD, data in cancer patients suggests a significant contribution of the most common polymorphisms (OPRM1 A118G, COMT Val158Met) to analgesic response to morphine. Patients with $C O M T$ and/or OPRM1 polymorphisms required $23 \%-93 \%$ more opioid than subjects with wild-type genes to achieve adequate analgesia. ${ }^{20}$

Many opioids are primarily metabolized by CYP2D6 to a more potent opioid agonist than the parent drug, and these include drugs such as hydrocodone, oxycodone, codeine, and tramadol. Yee et $\mathrm{al}^{21}$ analyzed CYP2D6 polymorphisms in African American children with SCD. Of the 75 children analyzed, 44\% were intermediate CYP2D6 metabolizers and 5.3\% were poor CYP2D6 metabolizers. Both of these phenotypes would decrease conversion of codeine, hydrocodone, and tramadol to their active metabolites, thereby decreasing analgesia.

A list of genes/polymorphisms involved in opiate metabolism is listed in Table 1.

\section{HbF inducers}

$\mathrm{HbF}$ is still present in normal adults, usually at levels $<1 \%$. This provides a therapeutic opportunity to upregulate $\mathrm{HbF}$ production. $\mathrm{HbF}$ expression has been found to be strongly associated with SNPs in three particular loci: Xmn1-HBG2, HBS1L-MYB, BCL11A. ${ }^{22}$ However, further study on the polymorphism showed that a downstream SNP, rs10128556, is more strongly associated with $\mathrm{HbF}$ expression than the Xmn1 site itself in African Americans with sickle cell anemia. ${ }^{23}$

One study showed that disruption of the BCL11A loci in a murine model increased the level of embryonic murine 
Table I Genes/polymorphisms involved in response to $\mathrm{HU}$ and leading to alterations in pain perception

\begin{tabular}{llll}
\hline HU & & & Opioids \\
\cline { 1 - 2 } \cline { 1 - 1 } Genes & & Polymorphisms & Genes \\
\cline { 1 - 2 } Positive & Negative & & \\
\hline XmnI & BAN haplotype & HBB locus (2 SNPs) & CYP2D6 \\
NOSI & CAM haplotype & MAP3K5 (2 SNPs intron I) & COMT \\
NOS2A & & SARIA (5 SNPs) & OPRMI \\
ASSI & HBSIL-MYB SNPs & ABCBI \\
ARGI & & UGT2B7 \\
ARG2 & & TLR4 \\
BCLIIA & & \\
KLFIO & & \\
PDE7B & & \\
TOX & & \\
\hline
\end{tabular}

Abbreviations: $\mathrm{HU}$, hydroxyurea; SNP, single-nucleotide polymorphism.

globin compared to adult globin. ${ }^{24}$ It is suggested that this same principle could be applied to human models and $\mathrm{HbF}$. Deng et $\mathrm{al}^{25}$ also showed that using zinc finger proteins to target $H b F$ promoter genes lead to $\mathrm{HbF}$ reactivation while reducing adult globin synthesis.

The role of genes was also elucidated by Ma et al, ${ }^{26}$ who highlighted the numerous SNPs in genes that can lead to increased $\mathrm{HbF}$ production, particularly the FLT1 gene polymorphism rs2182008. Other FLT1 gene polymorphisms were also found such as rs9319428 and rs8002446. Other genes found to be associated were MAP3K5, PDE7B, ASS, TOX, $A R G 1, A R G 2, N O S 2 A$, and NOS1.

Some studies have also suggested that KLF10 may act through a corepressor gene, $\operatorname{SIN} 3 \mathrm{~A}$. It has also been hypothesized that SIN3A, in conjunction with $H D A C 1$ gene, binds to KLF1 and represses KLF1 activity. This represses $\beta$-globin synthesis and, consequently, leads to an increase in fetal globin synthesis. ${ }^{27,28}$

Sheehan et $\mathrm{al}^{29}$ found a novel gene, SALL2, using whole exome sequencing, which was shown to lead to higher $\mathrm{HbF}$ expression level. The particular polymorphism is P840R SALL2.

Krivega et $\mathrm{al}^{30}$ studied the epigenetic effects of the G9a H3K9 methyltransferase on HbF induction. HBB transcription is regulated by the locus control region. The LDB1 complex brings the locus control region into direct contact with the gene. A chemical compound, UNC0638, inhibits the G9a methyltransferase, which allowed for more interaction between the LDB1 complex and the gamma globin promoters. This led to increased HbF production. The UNC0638 compound has poor in vivo pharmacokinetic properties, and so has limited clinical applications. However, this discovery provides an opportunity to study similar types of compounds that can serve as improved $\mathrm{HbF}$-inducing therapy. ${ }^{30}$
Additionally, a study found that expression of the LIN28 gene was found to decrease the amount of sickling in cultured human sickle cell sample and increase $\mathrm{HbF}$ expression. ${ }^{31}$

\section{NO inducers Endothelial Nitric Oxide Synthase polymorphisms}

NO deficiency has been shown to play an important role in the development of vaso-occlusive crises and endothelial dysfunction, of which a common complication is pulmonary hypertension. ${ }^{32,33} \mathrm{NO}$ is synthesized by nitric oxide synthase (NOS), and one isoform, endothelial NOS (eNOS), regulates the level of NO in the body. ${ }^{34}$ It is suggested that eNOS polymorphisms can be a prognostic marker for severity of SCD. ${ }^{35}$

There are SNPs of the eNOS gene associated with variations in NO levels. Some of these include 786T $>\mathrm{C}$ (rs2070744) in promoter region, 894G $>\mathrm{T}$ in exon 7 (Glu298Asp, rs1799983), and 4a/b, a 27-bp variable number of tandem repeats in intron 4 (chromosome $7 \mathrm{q} 35-\mathrm{q} 36$ ). ${ }^{35}$ Nishank et $\mathrm{al}^{36}$ found that there was a higher frequency of these particular polymorphisms in patients with severe SCD who had significantly lower levels of plasma nitrite compared to those in the mild SCD group. The homozygous 786T $>\mathrm{C}$ polymorphism decreases eNOS activity, leading to lower NO levels. ${ }^{37}$ Sharan et $\mathrm{al}^{38}$ found that the $786 \mathrm{~T}>\mathrm{C}$ polymorphism was associated with a higher likelihood of ACS in female African American patients with SCD. They proposed that this may be the first gender-specific modifier in SCD.

Patients with the eNOS4 alleles aa and ab genotypes were found to have a higher risk of vascular complications. ${ }^{39}$ Yousry, et $\mathrm{al}^{35}$ found the $4 \mathrm{a} / 4 \mathrm{~b}$ allele to be an independent risk factor for acute chest syndrome in their Egyptian population with SCD.

Conversely, Vargas et $\mathrm{al}^{40}$ found no association between these three main eNOS polymorphisms and SCD severity. Alternatively, the wild-type $4 \mathrm{a} / 4 \mathrm{~b}$ genotype was found to be protective against vaso-occlusive crises and pulmonary hypertension. ${ }^{35}$

\section{Relationship with L-arginine therapy}

There are renal complications from SCD, and the kidney is sensitive to the hypoxia induced by vaso-occlusion. ${ }^{41}$ Arginine is decreased in renal dysfunction given the loss of arginine synthesis from citrulline, which primarily occurs in the kidney. There can be a role for monitoring eNOS polymorphisms and arginine therapy. The $4 \mathrm{a} / 4 \mathrm{~b}$ allele had a higher frequency in SCD patients with nephropathy. ${ }^{37,39,42}$ In adults with SCD, it has been found that there is an arginine 
deficiency. ${ }^{43}$ In addition, low plasma arginine levels were shown to be predictive of hospitalization for children with SCD. ${ }^{43}$ Low arginine levels lead to increased arginase levels, which metabolizes arginine in another pathway, to ornithine and subsequently, polyamines and proline, which leads to smooth muscle proliferation airway remodeling. ${ }^{44}$ Understanding the eNOS polymorphisms can help direct arginine therapy.

\section{Relationship with adhesion molecule upregulation}

Vilas-Boas et $\mathrm{al}^{45}$ found that the SCD patients with the 786T $>$ C polymorphism had higher levels of sVCAM-1 levels. NO normally inhibits the expression of adhesion molecules, like sVCAM-1, which maintains normal endothelial function and blood flow. The upregulation of adhesion molecules contributes to vascular inflammation. ${ }^{46}$ VLA-4 is the very late activation antigen that is only expressed on sickled RBC membranes. ${ }^{47}$ Its receptor is VCAM-1, another immunoglobulin like ICAM-1. It is proposed that a possible treatment modality is antibodies to these two factors, which could decrease adhesion molecule upregulation.

\section{Conclusion}

There are few therapies approved for SCD treatment. Those that have been the most helpful, HbF inducers, HU, and opiates, have not displayed consistent results among patients, suggesting genetic influences. Many studies in this report have shown that genetic polymorphisms can influence the response to these treatments. Further studies are warranted to evaluate the impact on SCD treatment. Eventually, this approach would lead to more personalized approach for therapies in the field of SCD.

\section{Disclosure}

The authors report no conflicts of interest in this work.

\section{References}

1. Wang WC, Ware RE, Miller ST, et al. Hydroxycarbamide in very young children with sickle-cell anaemia: a multicentre, randomised, controlled trial (BABY HUG). Lancet. 2011;377(9778):1663-1672.

2. Patrinos GP, Innocenti F. Pharmacogenomics: paving the path to personalized medicine. Pharmacogenomics. 2010;11(2):141-146.

3. Patrinos GP, Grosveld FG. Pharmacogenomics and therapeutics of hemoglobinopathies. Hemoglobin. 2008;32(1-2):229-236.

4. Steinberg MH, Voskaridou E, Kutlar A, et al. Concordant fetal hemoglobin response to hydroxyurea in siblings with sickle cell disease. Am J Hematol. 2003;72(2):121-126.

5. Tafrali C, Paizi A, Borg J, et al. Genomic variation in the MAP3K5 gene is associated with $\beta$-thalassemia disease severity and hydroxyurea treatment efficacy. Pharmacogenomics. 2013;14(5):469-483.
6. Chalikiopoulou C, Tavianatou AG, Sgourou A, et al. Genomic variants in the ASS1 gene, involved in the nitric oxide biosynthesis and signaling pathway, predict hydroxyurea treatment efficacy in compound sickle cell disease/ $\beta$-thalassemia patients. Pharmacogenomics. 2016;17(4):393-403.

7. Gallienne AE, Dréau HM, Schuh A, Old JM, Henderson S. Ten novel mutations in the erythroid transcription factor KLF1 gene associated with increased fetal hemoglobin levels in adults. Haematologica. 2012;97(3):340-343.

8. Borg J, Phylactides M, Bartsakoulia M, et al. KLF10 gene expression is associated with high fetal hemoglobin levels and with response to hydroxyurea treatment in $\beta$ hemoglobinopathy patients. Pharmacogenomics. 2012;13(13):1487-1500.

9. Steinberg MH, Lu ZH, Barton FB, Terrin ML, Charache S, Dover GJ. Fetal hemoglobin in sickle cell anemia: determinants of response to hydroxyurea. Multicenter Study of Hydroxyurea. Blood. 1997;89(3):1078-1088.

10. Bakanay SM, Dainer E, Clair B, et al. Mortality in sickle cell patients on hydroxyurea therapy. Blood. 2005;105(2):545-547.

11. Kumkhaek C, Taylor JG, Zhu J, Hoppe C, Kato GJ, Rodgers GP. Fetal haemoglobin response to hydroxycarbamide treatment and sarla promoter polymorphisms in sickle cell anaemia. $\mathrm{Br} J$ Haematol. 2008;141(2):254-259.

12. Ware RE, Despotovic JM, Mortier NA, et al. Pharmacokinetics, pharmacodynamics, and pharmacogenetics of hydroxyurea treatment for children with sickle cell anemia. Blood. 2011;118(18):4985-4991.

13. Gravia A, Chondrou V, Sgourou A, et al. Individualizing fetal hemoglobin augmenting therapy for $\beta$-type hemoglobinopathies patients. Pharmacogenomics. 2014;15(10):1355-1364.

14. Alebouyeh M, Moussavi F, Haddad-Deylami H, Vossough P. Hydroxyurea in the treatment of major beta-thalassemia and importance of genetic screening. Ann Hematol. 2004;83(7):430-433.

15. Yavarian M, Karimi M, Bakker E, Harteveld CL, Giordano PC. Response to hydroxyurea treatment in Iranian transfusion-dependent beta-thalassemia patients. Haematologica. 2004;89(10):1172-1178.

16. Kohne E. Hemoglobinopathies: clinical manifestations, diagnosis, and treatment. Dtsch Arztebl Int. 2011;108(31-32):532-540.

17. Joly P, Gagnieu MC, Bardel C, Francina A, Pondarre C, Martin C. Genotypic screening of the main opiate-related polymorphisms in a cohort of 139 sickle cell disease patients. Am J Hematol. 2012;87(5):534-536.

18. Jhun EH, Yao Y, HeY, et al. Prevalence of pain-related single nucleotide polymorphisms in patients of African origin with sickle cell disease. Pharmacogenomics. 2015;16(16):1795-1806.

19. Nielsen LM, Olesen AE, Sato H, Christrup LL, Drewes AM. Association between gene polymorphisms and pain sensitivity assessed in a multi-modal multi-tissue human experimental model - An Explorative Study. Basic Clin Pharmacol Toxicol. 2016;119(4):360-366.

20. Reyes-Gibby CC, Shete S, Rakvåg T, et al. Exploring joint effects of genes and the clinical efficacy of morphine for cancer pain: OPRM1 and COMT gene. Pain. 2007;130(1-2):25-30.

21. Yee MM, Josephson C, Hill CE, et al. Cytochrome P450 2D6 polymorphisms and predicted opioid metabolism in African American children with sickle cell disease. J Pediatr Hematol Oncol. 2013;35(7): e301-e305.

22. Green NS, Barral S. Genetic modifiers of $\mathrm{HbF}$ and response to hydroxyurea in sickle cell disease. Pediatr Blood Cancer. 2011;56(2):177-181.

23. Galarneau G, Palmer CD, Sankaran VG, Orkin SH, Hirschhorn JN, Lettre G. Fine-mapping at three loci known to affect fetal hemoglobin levels explains additional genetic variation. Nat Genet. 2010;42(12):1049-1051.

24. Bauer DE, Kamran SC, Lessard S, et al. An erythroid enhancer of BCL11A subject to genetic variation determines fetal hemoglobin level. Science. 2013;342(6155):253-257.

25. Deng W, Rupon JW, Krivega I, et al. Reactivation of developmentally silenced globin genes by forced chromatin looping. Cell. 2014;158(4): 849-860. 
26. Ma Q, Wyszynski DF, Farrell JJ, et al. Fetal hemoglobin in sickle cell anemia: genetic determinants of response to hydroxyurea. Pharmacogenomics J. 2007;7(6):386-394.

27. Gravia A, Chondrou V, Kolliopoulou A, et al. Correlation of SIN3A genomic variants with $\beta$-hemoglobinopathies disease severity and hydroxyurea treatment efficacy. Pharmacogenomics. Epub 2016 Oct 21.

28. Siatecka M, Bieker JJ. The multifunctional role of EKLF/KLF1 during erythropoiesis. Blood. 2011;118(8):2044-2054.

29. Sheehan VA, Crosby JR, Sabo A, et al. Whole exome sequencing identifies novel genes for fetal hemoglobin response to hydroxyurea in children with sickle cell anemia. PLoS One. 2014;9(10):e110740.

30. Krivega I, Byrnes C, de Vasconcellos JF, et al. Inhibition of G9a methyltransferase stimulates fetal hemoglobin production by facilitating LCR/ $\gamma$-globin looping. Blood. 2015;126(5):665-672.

31. de Vasconcellos JF, Fasano RM, Lee YT, et al. LIN28A expression reduces sickling of cultured human erythrocytes. PLoS One. 2014;9(9):e106924.

32. Quimby KR, Hambleton IR, Landis RC. Intravenous infusion of haptoglobin for the prevention of adverse clinical outcome in Sickle Cell Disease. Med Hypotheses. 2015;85(4):424-432.

33. Wood KC, Hsu LL, Gladwin MT. Sickle cell disease vasculopathy: a state of nitric oxide resistance. Free Radic Biol Med. 2008;44(8):1506-1528.

34. Tsukada T, Yokoyama K, Arai T, et al. Evidence of association of the ecNOS gene polymorphism with plasma NO metabolite levels in humans. Biochem Biophys Res Commun. 1998;245(1):190-193.

35. Yousry SM, Ellithy HN, Shahin GH. Endothelial nitric oxide synthase gene polymorphisms and the risk of vasculopathy in sickle cell disease. Hematology. 2016;21(6):359-367.

36. Nishank SS, Singh MP, Yadav R, Gupta RB, Gadge VS, Gwal A. Endothelial nitric oxide synthase gene polymorphism is associated with sickle cell disease patients in India. J Hum Genet. 2013;58(12):775-779.

37. Elshamaa MF, Sabry S, Badr A, et al. Endothelial nitric oxide synthase gene intron4 VNTR polymorphism in patients with chronic kidney disease. Blood Coagul Fibrinolysis. 2011;22(6):487-492.
38. Sharan K, Surrey S, Ballas S, et al. Association of T-786C eNOS gene polymorphism with increased susceptibility to acute chest syndrome in females with sickle cell disease. Br J Haematol. 2004;124(2):240-243.

39. Tantawy AA, Adly AA, Ismail EA, Aly SH. Endothelial nitric oxide synthase gene intron 4 VNTR polymorphism in sickle cell disease: relation to vasculopathy and disease severity. Pediatr Blood Cancer. 2015;62(3): 389-394.

40. Vargas AE, da Silva MA, Silla L, Chies JA. Polymorphisms of chemokine receptors and eNOS in Brazilian patients with sickle cell disease. Tissue Antigens. 2005;66(6):683-690.

41. Ataga KI, Orringer EP. Renal abnormalities in sickle cell disease. $\mathrm{Am}$ J Hematol. 2000;63(4):205-211.

42. Wang Y, Kikuchi S, Suzuki H, Nagase S, Koyama A. Endothelial nitric oxide synthase gene polymorphism in intron 4 affects the progression of renal failure in non-diabetic renal diseases. Nephrol Dial Transplant. 1999;14(12):2898-2902.

43. Morris CR, Kuypers FA, Larkin S, Vichinsky EP, Styles LA. Patterns of arginine and nitric oxide in patients with sickle cell disease with vaso-occlusive crisis and acute chest syndrome. J Pediatr Hematol Oncol. 2000;22(6):515-520.

44. Morris CR, Kato GJ, Poljakovic M, et al. Dysregulated arginine metabolism, hemolysis-associated pulmonary hypertension, and mortality in sickle cell disease. JAMA. 2005;294(1):81-90.

45. Vilas-Boas W, Figueiredo CV, Pitanga TN, et al. Endothelial nitric oxide synthase $(-786 \mathrm{~T}>\mathrm{C})$ and endothelin-1 $(5665 \mathrm{G}>\mathrm{T})$ gene polymorphisms as vascular dysfunction risk factors in sickle cell anemia. Gene Regul Syst Bio. 2016;10:67-72.

46. Spiecker M, Darius H, Kaboth K, Hübner F, Liao JK. Differential regulation of endothelial cell adhesion molecule expression by nitric oxide donors and antioxidants. J Leukoc Biol. 1998;63(6):732-739.

47. Swerlick RA, Eckman JR, Kumar A, Jeitler M, Wick TM. Alpha 4 beta 1-integrin expression on sickle reticulocytes: vascular cell adhesion molecule-1-dependent binding to endothelium. Blood. 1993;82(6): 1891-1899.
Pharmacogenomics and Personalized Medicine

\section{Publish your work in this journal}

Pharmacogenomics and Personalized Medicine is an international, peerreviewed, open access journal characterizing the influence of genotype on pharmacology leading to the development of personalized treatment programs and individualized drug selection for improved safety, efficacy and sustainability. This journal is indexed on the American Chemical

\section{Dovepress}

Society's Chemical Abstracts Service (CAS). The manuscript management system is completely online and includes a very quick and fair peer-review system, which is all easy to use. Visit http://www.dovepress. com/testimonials.php to read real quotes from published authors. 